\title{
Genetic control of traits related to grain filling in the common bean
}

\author{
S.R. Guilherme, A.F.B. Abreu, R.R. da Silva and M.A.P. Ramalho \\ Departamento de Biologia, Universidade de Lavras, Lavras, Minas Gerais, \\ Brasil
}

Corresponding author: S.R. Guilherme

E-mail: scheilaguilherme@icloud.com

Genet. Mol. Res. 20 (1): gmr18697

Received August 13, 2020

Accepted January 18, 2020

Published February 28, 2021

DOI http://dx.doi.org/10.4238/gmr18697

\begin{abstract}
A possible strategy to increase grain yield in common beans (Phaseolus vulgaris) is to obtain lines with earlier flowering and a longer grain filling period, associated with a higher dry matter accumulation rate. We examined the genetic control of these traits to investigate whether it is possible to select lines with earlier flowering, a longer period of grain formation, and a higher dry matter accumulation rate in the grain. We also sought to determine whether it would be feasible to use these traits as an indirect selection strategy for grain yield. Ten lines belonging to the Andean and Mesoamerican gene pool were crossed in a diallel scheme in Lavras, MG. The hybrids together with the parents were evaluated in a randomized block design in three seasons, corresponding to generations $\mathrm{F}_{2}, \mathrm{~F}_{3}$ and $\mathrm{F}_{4}$. The variables measured were number of days to flowering (NDF), grain dry matter (GDM), grain yield (YIELD), number of days to physiological maturity (NDPM) and dry matter accumulation rate (RATE). We found that for NDF, NDPM and RATE, the general combining ability (GCA) explained most of the variation. Both GCA and the specific combining ability were important for YIELD. However, for this trait, the estimate of heterosis was significant, but negative (-27.7\%), when the crosses involved the Andean $x$ Mesoamerican lines. The estimated values of correlation between NDPM x NDF were positive $(0.72 * *)$, and negative between NDF x RATE $(-0.52 * *)$ and NDPM x RATE $(-0.43 *)$. Consequently, none
\end{abstract}


of the populations presented potential for obtaining new lines with high grain yield, based on indirect selection for early flowering and traits associated with grain filling.

Key words: Phaseolus vulgaris; Plant Breeding; Quantitative Genetics; Grain Production Physiology

\section{INTRODUCTION}

An increase in grain yield per area is the main goal of any plant-breeding program. It depends on practically every other trait of the plant. Nevertheless, some traits are especially related to yield. They are those involved in the expression of the primary components of yield. In the common bean, for example, they are the number of pods/plant, the number of seeds/pod, and 100-seed weight (Zilio et al., 2011; Lima and Ramalho, 2016). Among these traits, the weight of 100 seeds is directly associated with dry matter accumulation during the period of grain filling. This period is divided into three different stages: the early stage, so-called lag, in which the number of cells increases; the second one is the linear period of maximum dry matter accumulation; and the third one is the loss of water. Among the three stages, the one with a marked effect on grain yield is the second one, i.e., the linear stage. It is expected that any increase in the number of days during this stage will have a significant effect on final grain yield (Lee and Tollenaar, 2007).

Specifically, in the common bean, some studies have been conducted to understand how dry matter accumulates in grains (Cruz et al., 1993; Andrade et al., 2009; Taiz and Zeiger, 2013). However, they did not obtain detailed information concerning the variability of traits related to the rate of grain filling and mainly of the genetic control, as well as a probable association between them and grain yield. One report was found on common bean culture regarding the difference in the expression of genes involved in flowering and grain filling; however, they were associated with drought tolerance (Müller, et al. 2014). There are reports of traits associated with the period of grain filling in other species such as maize (Gasura et al., 2013) and wheat (Aude et al., 1994), yet with no information on genetic control.

The common bean crop has a short growing cycle when compared to other species. From sowing to harvesting, the cycle barely exceeds 80-90 days for the current cultivars. However, there are still some attempts to reduce this cycle even more so that the crop may have more flexibility to participate in succession systems with different species, mostly in irrigated areas. But, to have an average yield in common bean exceeding current levels, it would be necessary to extend the period of dry matter accumulation in grains-grain fillingwithout affecting the length of the cycle as a whole; that is, reducing the time needed for flowering to start. Unfortunately, there is no information if such a strategy would be feasible. Given the above, we aimed to obtain information on the genetic control of the traits related to bean grain filling, including length of dry matter accumulation period and dry matter accumulation rate. In addition, we sought to investigate whether it is possible to select lines with early flowering, but with a longer period of accumulation of grain filling. Finally, we sought to determine whether it is feasible to use such traits as a strategy for indirect selection for grain yield. 


\section{MATERIAL AND METHODS}

The experiments were carried out in the experimental area of the Technology Development Center at the Federal University of Lavras (UFLA), located in Southern Minas Gerais State, at 919 meters altitude, $21^{\circ} 14$ ' South latitude and 45 " West longitude.

Ten lines (Table 1) of common bean comprising both the Andean and the Mesoamerican gene pools were used. They differ in several traits notably associated with grain filling such as grain mass and growing habit of the plant.

Table 1. Identification and main traits of the parents used in the experiments carried out to investigate traits related to flowering and grain filling in the common bean.

\begin{tabular}{lllll}
\hline Lines & Gene pool & Growth habit & Color of grains & 100-seed mass (g) \\
\hline 1 Eriparsa & Andean & Determined & Cream & 30 \\
2 Madrepérola & Mesoamerican & Undetermined & Carioca & 25 \\
3 Manteigão Fosco & Andean & Determined & White & 35 \\
4 Talismã & Mesoamerican & Undetermined & Carioca & 24 \\
5 Goiano Precoce & Andean & Determined & Cream & 30 \\
6 Flor de Mayo & Mesoamerican & Undetermined & Pink-cream & 22 \\
7 Pérola & Mesoamerican & Undetermined & Carioca & 25 \\
8 MAII-22 & Mesoamerican & Undetermined & Carioca & 25 \\
9 Amarelinho & Mesoamerican & Undetermined & Yellow & 20 \\
10 Paraná & Mesoamerican & Undetermined & Carioca & 20 \\
\hline
\end{tabular}

A diallelic crossing with the 10 lines of common bean was carried out. Out of 45 possible hybrid combinations, 39 were obtained. The seeds from the $F_{1}$ generation were sown in the field to obtain the seeds of the $F_{2}$ generation. The 39 hybrids along with the parents were evaluated in three different seasons. The first $F_{2}$ generation was sown in November, with three replicates; the second one, $\mathrm{F}_{3}$, was sown in February of the next year; and the third one, $\mathrm{F}_{4}$, was sown in July. The last two had four replicates. The experimental design was completely randomized. The plots consisted of three 4-meter-long lines with 10 seeds/linear meter. The space between lines was $60 \mathrm{~cm}$. The cultural practices were those usually adopted for the crop in the region (Ramalho et al., 2014).

The variables measured and analyzed were: $i$ ) the number of days to the beginning of flowering (NDF - days), that is, the number of days from sowing until the moment when $50 \%$ of plants had at least one open flower; ii) grain dry matter (GDM - g/grain), collected from seven days after the beginning of flowering on. Afterwards, the samples were collected at regular intervals of five days. For each sampling carried out on two lines of the plot, five pods of the same size were collected. The pods were then taken to the laboratory, and the grains were counted and weighed to measure the green matter. After that, they were placed in paper bags and taken to dry in a forced air circulation oven at approximately $65^{\circ} \mathrm{C}$ for a 72-hour period. After drying, they were weighed once again to record the dry matter, in g/grain; iii) grain yield (YIELD - kg/plot): one of the two lateral lines of the plot with no previous sampling of pods was harvested. The plants were harvested and the weight of grains per plot was obtained; iv) the number of days to physiological maturity (NDPM).

The equation of dry matter accumulation was determined through a second-degree equation by using data of dry matter per grain, dependent variable $(\mathrm{Y})$ per sampling date, independent variable $(\mathrm{X})$. From this equation, the maximum point was estimated per plot. 
This point was the reference to calculate the number of days to physiological maturity (NDPM), i.e., the number of days from the beginning of flowering up to physiological maturation; $v$ ) daily linear rate of dry matter accumulation per grain (RATE - g/grain/day). From these data, a linear regression equation between the independent variable $(\mathrm{X})$ number of days from sampling - and the dependent variable $(\mathrm{Y})$ - dry matter per plot - was determined. The estimation of $b$ in the linear equation was used as the RATE, in other words, the accumulation of dry matter per grain per day. Data of YIELD, NDF, NDPM, and RATE were subjected to the analysis of variance according to the growing season at first. Subsequently, the joint analyses of the three generations were carried out.

By using the means of the analyses, the estimations of the genetic parameters were accounted through a diallelic analysis according to Griffing - Method II (1966) with the aid of the model presented by Cruz et al. (2012). The statistical analyses were performed with the software GENES (Cruz, 2013) as well as the software R (R Core Team, 2017). The phenotypic correlation coefficients of the traits were estimated two by two.

\section{RESULTS AND DISCUSSION}

It must be emphasized that six out of 45 hybrid combinations (HC) did not succeed. They involved crossings from the Mesoamerican lines "Flor de Mayo" and "Talismã" with the Andean lines "Eriparsa", "Goiano Precoce", and "Manteigão Fosco". It is due to an incompatibility phenomenon widely studied (Shii et al., 1981; Vilarinho et al., 2004; Bruzi et al., 2007; Borel et al., 2016).

In developing such research, especially with a leguminous species, some difficulties may arise. In this way, research on the rate of dry matter accumulation in the literature is predominant in maize (Borráz et al., 2003; Borráz et al., 2009; Gasura et al., 2013). One of these difficulties is related to sampling. In common bean, the flowering period extends for 10 or more days (Ramalho and Ferreira, 1979). Furthermore, the successful flowering is relatively low (Reis et al., 1985; Guilherme, Ramalho et al., 2014; Martins et al., 2017) and the flower / pods that abort are usually those from the end of flowering (Ramalho and Ferreira, 1979).

Thus, as noted at the beginning of flowering, the sampling period had this date as a reference. Provided the pods arise in different periods, the pods collected not always represented the desired date of collection. There was considerable concern to choose visually same-sized pods in each sampling. Another variable is that there can be variation in the size of grains within a single pod that, of course, may change the results of dry matter at each season.

Because segregating populations were used, the ideal was to have the highest number of pods/plants to represent each segregating population. Five pods were taken per plot. Considering that the experiments had three replicates in $\mathrm{F}_{2}$ and four replicates in $\mathrm{F}_{3}$ and $\mathrm{F}_{4}$, and also that each pod has on average four to five seeds, it is possible to infer that each segregating population had 80 to 100 seeds in $\mathrm{F}_{3}$ and $\mathrm{F}_{4}$ generations. This number is likely to represent each population. It should be emphasized that the manual work in each sampling to open each pod and to remove the developing grains with little or no damage was hard, mostly in the first samplings.

Another difficulty with common bean is to have a reference of the moment when there is the maximum accumulation of dry matter. In maize, for example, the occurrence of 
the black layer is the reference that there will be no more accumulation of dry matter in that grain (Araujo et al., 2006). In "Carioca" common bean grain type, i.e., cream with brownish streaks, there is information that the maximum accumulation of dry matter takes place as with the emergence of the streaks in the seed coat (Vieira and Vieira, 1997). This is easily observed, but it is only valid for this type of grain. Most of the parents did not have this type of grain, and even when the parent was 'Carioca' crossed with another non-carioca line, there is segregation either with or without streaks thus it was not possible to use such a criterion to identify the final moment of physiological maturation.

The strategy to identify this moment was to use a second-degree equation (Cruz et al., 1993). The period of maximum dry matter accumulation was estimated. It is considered to be the end of the physiological maturation. It was not always easy to find this maximum period, mainly due to sampling errors as already described. However, the high estimations of the coefficient of determination - data not shown -, make it possible to have credibility in the equations determined. From this maximum period, the moment - days - after sowing when the end of the physiological maturity happened was identified. Provided the difference between this number of days and the number of days to the beginning of flowering, the number of days to physiological maturation was determined.

In the present study, the $b$ from the linear regression between the independent variable $(\mathrm{X})$ - number of days to filling - and the dependent variable $(\mathrm{Y})$ - dry matter per grain - was chosen to be used at the determined moment. One of the drawbacks of this RATE is that it considers that the accumulation of dry matter is supposed to be the same throughout grain filling. Indeed, dry matter accumulation is not constant throughout the process, from flowering to harvesting. Some researchers claim that there are three phases along this period (Lee and Tollenaar, 2007). The first one is relatively short, it is termed lag, and it goes from the fertilization to the moment when there is intense accumulation of dry matter in grains. In the lag phase, there are several cell divisions in order to increase the number of cells in grains (Lee and Tollenaar, 2007). When it comes to bean plants, there are no reports of how long the lag phase lasts. The use of the linear equation, at least in principle, allows for a good comparison of the rate.

The next phase, also known as the effective period of dry matter accumulation, is named linear phase because there is a large linear accumulation of dry matter in the grain. According to Lee and Tollenaar (2007), more than $90 \%$ of the total dry matter in the grain is accumulated during the linear phase in grass species. Ultimately, this phase is the focus of studies, since the length and rate of dry matter accumulation in this phase will reflect in the productivity of grains of the plant.

There are significant differences in the means of the generations for all traits (Table 2). The sources of variations, treatment and treatment $x$ generations $(T \times G)$, were significant for all traits. Although interactions $\mathrm{T}$ x $\mathrm{G}$ were significant, emphasis was given to the results covering the means of the three generations. The significance of the interaction is usual in experiments conducted with common bean in the region (Lima et al., 2013; Ferreira et al., 2015). However, despite the interaction between T x G, it is not possible to mitigate this effect from a practical point view since it would be unfeasible to recommend a given genotype for each growing season. Therefore, the alternative is to interpret data by taking into account the means of the three seasons. By doing so, the inferences related to treatments will be more accurate once each mean being considered is 
from 11 replicates, i.e., the means of the three harvesting seasons with three to four replicates/season at each season/generation.

Table 2. Summary of the joint analyses of variance and the diallel analysis (Griffing1956) for the following traits: number of days to the beginning of flowering (NDF - days), number of days to physiological maturity (NDPM - days), rate of grain filling (RATE $-\mathrm{g}$ grain $^{-1}$ day $^{-1} \times 10^{3}$ ) and yield (YIELD $-\mathrm{kg} / \mathrm{plot}$ ). Data from three generations of a diallelic crossing of common bean lines.

\begin{tabular}{|c|c|c|c|c|c|}
\hline FV & DF & NDF & NDPM & RATE & YIELD \\
\hline Treatment $(\mathrm{T})$ & 48 & $52.56^{* *}$ & $102.72^{* *}$ & $10.38^{* *}$ & $0.14^{* *}$ \\
\hline G.C.A. & 9 & $252.63^{* *}$ & $390.23^{* *}$ & $30.22^{* *}$ & $0.28^{* *}$ \\
\hline S.C.C. & 39 & $5.27^{\text {ns }}$ & $35.86^{* *}$ & $5.44^{* *}$ & $0.11^{* *}$ \\
\hline Generations (G) & 2 & $11338.25^{* *}$ & $33.65^{* *}$ & $69.85^{* *}$ & $13.12^{* *}$ \\
\hline $\mathrm{T} \times \mathrm{G}$ & 96 & $20.45^{* *}$ & $21.99^{* *}$ & $2.73^{* *}$ & $0.07^{* *}$ \\
\hline GCA X G & 18 & $71.24^{* *}$ & $136.72^{* *}$ & $9.85^{* *}$ & $0.07^{* *}$ \\
\hline SCA X G & 78 & $1.00^{\mathrm{ns}}$ & $5.78^{\text {ns }}$ & $1.32^{* *}$ & $0.02^{* *}$ \\
\hline Residual & 384 & 4.05 & 7.8 & 0.87 & 0.02 \\
\hline General mean & & 43.17 & 38.43 & 6.52 & 0.57 \\
\hline
\end{tabular}

${ }^{* *}$ Significant according to the $\mathrm{F}$ test at $1 \%$ probability. ${ }^{\text {ns }}$ not significant according to the $\mathrm{F}$ test. GCA: general combining ability; SCA: specific combining ability.

By using the means of the traits evaluated, it was found that the NDF was similar for $F_{2}$ and $F_{3}$ generations. Regarding the $F_{4}$ generation, the flowering was late (Table 3). It was observed, though, that there was a difference of only one day for NDPM in comparison to the generation with the highest mean $\left(\mathrm{F}_{3}\right)$ as well as the earliest $\left(\mathrm{F}_{4}\right)$. Such a difference was only significant, probably, due to the high accuracy $\left(\mathrm{r}_{\mathrm{gg}}\right)$ of the experiments for this trait. As to the rate of daily accumulation of dry matter (RATE), the range of variation between generations was $18.9 \%$ of the estimation of the general mean. In the mean of the three generations, the daily accumulation of dry matter was $6.52 \times 10^{-3} \mathrm{~g} / \mathrm{grain} / \mathrm{day}$. With respect to grain yield (YIELD), it was noted that the range of variation between generations was $63.6 \%$ of the estimation of the general mean (Table 3 ).

Table 3. Means of parents and hybrids for the traits: number of days to flowering (NDF - days), number of days to physiological maturity (NDPM - days), rate of dry matter accumulation (RATE) $\left(\mathrm{g}_{\text {grain }}{ }^{-1}\right.$ day $\left.^{-1}\right)(\mathrm{x}$ $10^{3}$ ) and grain yield (YIELD - kg/plot). Data from three generations of the diallelic crossing of common bean lines. Lavras, MG.

\begin{tabular}{|c|c|c|c|c|c|}
\hline & & $\mathbf{F}_{2}$ & $\mathbf{F}_{3}$ & $\mathrm{~F}_{4}$ & General mean \\
\hline & Parents & 40.37 & 37.85 & 51.95 & 43.39 \\
\hline \multirow[t]{3}{*}{ NDF } & Hybrids & 39.56 & 37.57 & 51.69 & 42.94 \\
\hline & Mean & 39.97 & 37.71 & 51.82 & 43.17 \\
\hline & Parents & 39.10 & 39.88 & 38.98 & 39.32 \\
\hline \multirow[t]{3}{*}{ NDPM } & Hybrids & 37.22 & 37.91 & 37.48 & 37.54 \\
\hline & Mean & 38.16 & 38.90 & 38.23 & 38.43 \\
\hline & Parents & 7.44 & 6.97 & 6.37 & 6.93 \\
\hline \multirow[t]{3}{*}{ RATE } & Hybrids & 7.03 & 6.62 & 5.54 & 6.40 \\
\hline & Mean & 7.06 & 6.66 & 5.83 & 6.52 \\
\hline & Parents & 0.91 & 0.52 & 0.35 & 0.59 \\
\hline \multirow[t]{2}{*}{ YIELD } & Hybrids & 0.84 & 0.49 & 0.29 & 0.54 \\
\hline & Mean & 0.88 & 0.51 & 0.32 & 0.57 \\
\hline
\end{tabular}


When there is dominance in the expression of the trait, the mean of the segregating population was expected to decrease as was the case for the $\mathrm{F}_{4}$ generation. Nevertheless, as it will be commented below, the dominance was not expressive for most of the traits. Thus, under the point of view of the genetics, the mean of the generations should be similar. However, it must be emphasized that the climate of the three seasons in the region are distinct with respect to temperature and especially rainfall (Santos et al., 2015). Therefore, much of the effect of $F_{2}, F_{3}$, and $F_{4}$ generations evaluated was related to the environmental factor owed to different growing seasons.

At first, common bean breeders aim to have one plant with undetermined growth habit, as erect as possible, and that start flowering as early as possible. In addition to that, they also expect that flowering lasts from 10 to 15 days in order to mitigate the possible effects of a climate problem. Moreover, there should be focus on having the longest grain filling as possible since it is responsible for the grain yield of the plant.

Concerning the mean between parents and hybrids, it is observed that there was a difference of only one day for NDPM, in other words, $2.6 \%$ heterosis in relation to the mean of parents. The general mean of hybrids was $7.64 \%$ to RATE, lower than that observed to parents. It is noteworthy that for both traits the heterosis estimated was in the sense of reducing the expression of the trait. When it comes to NDF, the general mean of hybrids was very similar to that recorded to the parents across all generations, i.e., heterosis practically null. With respect to parents, there was a marked variation for NDF (Table 4). Those from the Andean gene pool ('Eriparsa' and 'Goiano Precoce') were the ones that required the lowest number of days to start flowering. Among parents belonging to the Mesoamerican group, the difference ranged from 44.3 to 45.7 days.

Table 4. Means of the traits: number of days to flowering (NDF - days) (above the diagonal) and number of days to physiological maturity (NDPM - days) (below the diagonal). Data from three generations of the diallelic crossing of common bean lines. Lavras, MG.

\begin{tabular}{|c|c|c|c|c|c|c|c|c|c|c|c|}
\hline Parents $^{1}$ & 10 & 8 & 1 & 3 & 6 & 4 & 9 & 5 & 7 & 2 & Parents \\
\hline 10 & & $44.3 b$ & $40.3 a$ & $41.3 \mathrm{a}$ & $44.6 b$ & $44.6 \mathrm{~b}$ & $46.3 b$ & $40.3 b$ & $45.3 b$ & $45.3 b$ & $45.6 b$ \\
\hline 8 & $43.0 \mathrm{~b}$ & & $41.3 \mathrm{a}$ & $41.3 \mathrm{a}$ & $44.3 b$ & - & $45.3 b$ & $41.0 \mathrm{~b}$ & $44.6 \mathrm{~b}$ & $44.0 \mathrm{~b}$ & $45.0 \mathrm{~b}$ \\
\hline 1 & $35.6 \mathrm{a}$ & $35.0 \mathrm{a}$ & & $39.6 \mathrm{a}$ & - & $41.3 b$ & $41.3 b$ & $38.3 \mathrm{a}$ & $40.6 \mathrm{~b}$ & $41.0 \mathrm{~b}$ & $39.0 \mathrm{a}$ \\
\hline 3 & $38.0 \mathrm{a}$ & $36.6 \mathrm{a}$ & $35.6 \mathrm{a}$ & & - & - & $42.6 b$ & $39.6 \mathrm{~b}$ & $42.6 b$ & $42.6 b$ & $41.6 \mathrm{~b}$ \\
\hline 6 & $41.6 b$ & $43.0 \mathrm{~b}$ & - & - & & - & $44.6 \mathrm{~b}$ & - & $45.0 \mathrm{~b}$ & $44.3 b$ & $44.6 \mathrm{~b}$ \\
\hline 4 & $38.6 \mathrm{~b}$ & - & $35.6 \mathrm{a}$ & - & - & & $45.00 \mathrm{~b}$ & $41.0 \mathrm{~b}$ & $45.6 \mathrm{~b}$ & $44.3 b$ & $45.0 \mathrm{~b}$ \\
\hline 9 & $42.6 b$ & $41.3 \mathrm{~b}$ & $36.0 \mathrm{a}$ & $38.3 \mathrm{a}$ & $41.0 \mathrm{~b}$ & $40.3 b$ & & $41.6 b$ & $46.3 b$ & $45.3 b$ & $45.6 \mathrm{~b}$ \\
\hline 5 & $36.3 \mathrm{a}$ & $34.0 \mathrm{a}$ & $35.3 \mathrm{a}$ & $36.0 \mathrm{a}$ & - & $36.0 \mathrm{a}$ & $34.6 \mathrm{a}$ & & $40.0 \mathrm{~b}$ & $40.0 \mathrm{~b}$ & $38.6 a$ \\
\hline 7 & $41.6 b$ & $39.6 b$ & $37.3 \mathrm{a}$ & $38.0 \mathrm{a}$ & $41.3 b$ & $38.6 \mathrm{a}$ & $36.0 \mathrm{a}$ & $34.0 \mathrm{a}$ & & $45.3 b$ & $45.6 b$ \\
\hline 2 & $38.6 \mathrm{~b}$ & $38.3 \mathrm{a}$ & $34.6 \mathrm{a}$ & $36.0 \mathrm{a}$ & $37.6 \mathrm{a}$ & $36.0 \mathrm{a}$ & $37.3 \mathrm{a}$ & $35.0 \mathrm{a}$ & $39.6 \mathrm{~b}$ & & $44.3 b$ \\
\hline Parents & $43.3 b$ & $44.0 \mathrm{~b}$ & $35.0 \mathrm{a}$ & $34.3 \mathrm{a}$ & $43.3 b$ & $34.6 \mathrm{a}$ & $43.0 \mathrm{~b}$ & $36.3 a$ & $43.6 \mathrm{~b}$ & $36.67 \mathrm{a}$ & \\
\hline
\end{tabular}
described in Table 1 .

Important information concerns the average rate of dry matter accumulation in grains. It can be observed in Table 5 that the parent with the lowest RATE was 'Amarelinho' ( $4.90 \times 10^{-3} \mathrm{~g}_{\text {grain }^{-1}}$ day $^{-1}$ ) while the highest one was 'Manteigão Fosco' $\left(9.24 \times 10^{-3}{\text { g } \text { grain }^{-1} \text { day }}^{-1}\right)$, i.e., a range of $88.6 \%$ variation of parents in comparison to 'Amarelinho'. Among hybrids, the pairs 'Goiano Precoce' x 'Madrepérola' $\left(5.11 \times 10^{-3} \mathrm{~g}\right.$ grain $^{-1}$ day $\left.^{-1}\right)$ and 'Manteigão Fosco' x 'Eriparsa' $\left(8.45 \times 10^{-3}\right.$ g grain $^{-1}$ day $\left.{ }^{-1}\right)$ were in the 
extreme positions, that is a range of $65.3 \%$ variation in relation to the hybrid with the lowest RATE.

Table 5. Means of the traits: dry matter accumulation rate (RATE $-\mathrm{g}$ grain $^{-1}$ day $\left.^{-1}\right)\left(\mathrm{x} 10^{3}\right)($ above the diagonal) and grain yield (YIELD - kg/plot) (below the diagonal). Data from three generations of the diallelic crossing of common bean lines. Lavras, MG.

\begin{tabular}{|c|c|c|c|c|c|c|c|c|c|c|c|}
\hline Parents $^{1}$ & 10 & 8 & 1 & 3 & 6 & 4 & 9 & 5 & 7 & 2 & Parents \\
\hline 10 & & $5.5 \mathrm{a}$ & $5.5 \mathrm{a}$ & $6.5 b$ & $6.3 b$ & $5.8^{\mathrm{a}}$ & $5.5 \mathrm{a}$ & $6.8 b$ & $6.3 \mathrm{~b}$ & $6.3 b$ & $5.1 \mathrm{a}$ \\
\hline 8 & $0.6 \mathrm{a}$ & & $7.6 \mathrm{~b}$ & $6.5 b$ & $5.4 \mathrm{a}$ & - & $5.9 \mathrm{a}$ & $7.4 b$ & $6.8 \mathrm{~b}$ & $6.5 b$ & $7.4 \mathrm{~b}$ \\
\hline 1 & $0.5 b$ & $0.4 \mathrm{~b}$ & & $8.4 \mathrm{~b}$ & - & 6.4 & $6.2 \mathrm{~b}$ & $8.2 b$ & $6.8 \mathrm{~b}$ & $6.3 b$ & $8.8 b$ \\
\hline 3 & $0.5 b$ & $0.3 b$ & $0.6 \mathrm{a}$ & & - & - & $5.4 \mathrm{a}$ & $7.4 \mathrm{~b}$ & $6.6 \mathrm{~b}$ & $6.3 b$ & $9.2 b$ \\
\hline 6 & $0.6 \mathrm{a}$ & $0.6 \mathrm{a}$ & - & - & & - & $6.5 b$ & - & $6.0 \mathrm{~b}$ & $6.4 b$ & $5.3 \mathrm{a}$ \\
\hline 4 & $0.7 \mathrm{a}$ & - & $0.4 b$ & - & - & & $5.6 \mathrm{a}$ & $5.6 \mathrm{a}$ & $6.2 b$ & $6.8 b$ & $6.6 \mathrm{~b}$ \\
\hline 9 & $0.6 \mathrm{a}$ & $0.6 \mathrm{a}$ & $0.4 b$ & $0.3 \mathrm{~b}$ & $0.4 b$ & $0.6^{\mathrm{a}}$ & & $6.5 b$ & $5.8 \mathrm{a}$ & $5.9 \mathrm{a}$ & $4.9 \mathrm{a}$ \\
\hline 5 & $0.5 b$ & $0.5 b$ & $0.6 \mathrm{a}$ & $0.5 b$ & - & $0.4 \mathrm{~b}$ & $0.4 \mathrm{~b}$ & & $6.7 \mathrm{~b}$ & $5.1 \mathrm{a}$ & $8.3 b$ \\
\hline 7 & $0.7 \mathrm{a}$ & $0.7 \mathrm{a}$ & 0.4 & $0.3 b$ & $0.6 \mathrm{a}$ & $0.6^{\mathrm{a}}$ & 0.4 & $0.5 b$ & & $6.8 b$ & $7.3 b$ \\
\hline 2 & $0.6 \mathrm{a}$ & $0.6 \mathrm{a}$ & 0.4 & $0.3 \mathrm{~b}$ & $0.5 \mathrm{a}$ & $0.6^{\mathrm{a}}$ & 0.4 & $0.4 b$ & $0.7 \mathrm{a}$ & & $6.0 \mathrm{~b}$ \\
\hline Parents & $0.7 \mathrm{a}$ & $0.7 \mathrm{a}$ & $0.6 \mathrm{a}$ & $0.6 \mathrm{a}$ & $0.4 \mathrm{~b}$ & $0.7^{\mathrm{a}}$ & 0.4 & $0.6 \mathrm{a}$ & $0.6 \mathrm{a}$ & $0.6 \mathrm{a}$ & \\
\hline
\end{tabular}

In the means of the three generations, it was found that the parents 'Flor de Mayo' and 'Amarelinho' had the lowest score for yield while 'Talismã' performed the best. There was a range of variation of $0.28 \% \mathrm{~kg} / \mathrm{plot}$. With respect to hybrid combinations (HC), the variation was also meaningful with $0.30 \mathrm{~kg} /$ plot ('Pérola' x 'Manteigão Fosco') and 0.76 $\mathrm{kg} /$ plot ('Pérola' x MAII-22).

It is well-known that Andean beans are precocious especially because all of those used in present study had determined growth. Yet, there are no reports on the length of NDPM for these parents. There is information in the literature concerning the genetic control of NDF (Oliveira et al., 1996; Mendes et al., 2008). Overall, research indicates that there is a predominance of the additive effect, as observed in this study (Table 2). The means of the parents were 43.4 and $42.9 \%$ of those of the hybrids, i.e., the heterosis was of small magnitude and in the sense of reducing the expression of the trait, as desired by breeders (Table 3 ).

As for the general mean, the parents had a better performance for grain yield (g/plot) when compared to the hybrids (Table 3). In such a condition for this trait, it can be inferred that there is heterosis, but in the sense of reducing the expression of the trait. In the literature, there are reports that the allelic interaction of dominance is less important than the additive one (Moreto et al., 2007; Baldoni et al., 2008; Martins et al., 2017). Nevertheless, there are reports that dominance may have a marked effect on grain yield (Chung and Stevenson, 1973; Foolad and Bassiri, 1983; Pereira et al., 2007; Guilherme et al., 2014). Still, this dominance is in the sense of improving the expression of the trait and not in the sense of reducing its expression as occurred in this study.

It must be emphasized that the estimation of the heterosis for YIELD, when considering only Mesoamerican x Mesoamerican hybrids was null, as also occurred to Andean $x$ Andean hybrids. Yet, the hybrids between both gene pools, Mesoamerican $\mathrm{x}$ Andean, the heterosis was $27.7 \%$, that is, it had a greater magnitude, and it was negative. On several occasions, common bean breeders aim at increasing the variability by means of 
hybridization of Andean x Mesoamerican lines. On almost every occasion, it was also reported that the hybrid population performs lower than the mean of the parents, i.e., there was also a negative heterosis (Silva et al., 2004; Borel et al., 2016). The explanation for the occurrence of negative heterosis for grain yield has been studied and the information available indicates a possible effect of epistasis (Moreto et al., 2012; Borel et al., 2013; Borel et al., 2016). On the other hand, these two gene pools originate from very distinct regions and it is likely that during successive cultivation in such regions, genotypic combinations favorable to each condition may have developed. Therefore, provided these parents from both gene pools have already been cultivated in Brazil for a long time, the favorable genotypic combinations developed in the past remain connected in the chromosomes as if they were gene blocks. When crossing Andean $\mathrm{x}$ Mesoamerican, part of these combinations are undone and the new genotypic combinations have lower adaption than their parents do.

In the diallelic analysis through Griffing's Method II (1956), it was found that there was a significant difference $(\mathrm{P} \leq \mathrm{m} 0.01)$ for the general combining ability (GCA) for all traits investigated. There was also a significant difference for the specific combining ability (SCA) for NDPM and RATE (Table 2). However, the ratio of square sum (SQ) explained by the GCA was higher than SCA, that is, $71.3 \%$ of the SQ of treatments for NDPM and $54.6 \%$ for RATE. These findings corroborate our previous comments that the heterosis was of small magnitude. Regarding YIELD, there was a significant difference for both GCA and SCA, but it is observed that the SQ explained by the SCA was higher than GCA (56.4\%) for the same trait.

The estimations of GCA's $\left(g_{i}\right)$ for all traits are presented in Table 6 . With respect to NDF, the parents 'Eriparsa' and 'Goiano Precoce' accounted for the decrease in the expression of the trait because they had higher, negative scores of GCA $\left(g_{i}\right)$. The parents 'Amarelinho' and 'Pérola' have also stood out by accounting for an increase in the NDPM in crossings, with positive scores of $g_{i}$. The positive scores of $g_{i}$ for RATE were observed for the parent 'Flor de Mayo' and for YIELD by the parent 'Paraná'.

Table 6. Mean scores of the general combining ability (GCA) for number of days to flowering (NDF days), number of days to physiological maturity (NDPM - days), rate of dry matter accumulation (RATE) $\left(\mathrm{g}\right.$ grain $^{-1}$ day $\left.^{-1}\right)\left(\mathrm{x} 10^{3}\right)$, and grain yield (YIELD - kg/plot). Data from mean of three generations of diallelic crossing of common bean lines. Lavras, MG.

\begin{tabular}{lcccc}
\hline \multirow{2}{*}{ PARENTS } & \multicolumn{3}{c}{ GCA } \\
\cline { 2 - 4 } & NDF & NDPM & RATE & YIELD \\
\hline Paraná & 0.90 & 0.34 & 1.95 & 0.08 \\
MAII-22 & 0.64 & 0.42 & 1.51 & 0.05 \\
Eriparsa & -2.50 & -0.72 & -2.18 & -0.02 \\
Manteigão Fosco & -1.22 & -0.66 & -1.48 & -0.07 \\
Flor de Mayo & 0.71 & 0.31 & 2.18 & -0.02 \\
Talismã & 0.89 & -0.21 & -0.92 & 0.05 \\
Amarelinho & 1.40 & 0.69 & 1.17 & -0.05 \\
Goiano Precoce & -2.74 & -0.47 & -2.30 & -0.04 \\
Pérola & 1.15 & 0.50 & 1.17 & 0.03 \\
Madrepérola & 0.65 & -0.24 & -1.08 & 0.01 \\
\hline
\end{tabular}

The scores of SCA ranged widely for all traits (data not shown). For NDF, the combinations 'Goiano Precoce' x 'Pérola', 'Paraná' x 'Manteigão Fosco' and MaII-22 x 'Manteigão Fosco' are noteworthy, since they had negative SCA. For NDPM, the hybrid combinations with the highest positive SCA scores were 'Flor de Mayo' $\mathrm{x}$ 'Amarelinho' and 'Talismã' $\mathrm{x}$ 'Madrepérola'. For RATE, the hybrid combinations that stood out the most for SCA 
were 'Talismã' x 'Amarelinho', 'Eriparsa' x 'Goiano Precoce', and 'Manteigão Fosco' x 'Goiano Precoce'. For YIELD, the best performances were observed for the HC 'Eriparsa' x 'Manteigão Fosco' and 'Pérola' x 'Madrepérola'.

Regardless of the trait, when there is either no dominance or it is of small magnitude, the choice of the parents can be made based on the scores of the general combining ability $\left(g_{i}\right)$. In turn, the association of the $g_{i}$ score with the mean is supposed to be high and positive in this condition (Ramalho et al., 2012). This fact was proved for most of the traits.

Correlations estimates between traits two by two is presented in Table 7. The highest estimate of correlation was between NDF and NDPM (0.72). It was expected to be negative and towards the shortest number of days to flowering and longest number of days to physiological maturity. This estimate shows that the possibility of breeders succeed in selecting both traits as desired may be hindered. The estimate of the correlation RATE and NDPM (-0.43) was also towards the undesirable, that is, the parents or segregating populations with the longest number of days to physiological maturity had lower accumulation of dry matter in grains. There were no reports in this regard on common bean. Based on these results, the $r$ estimates involving yield ranged according to the trait. It was not significative for RATE and significative, positive for NDF and NDPM, but not of great magnitude. It is apparent, especially for NDPM - RATE and YIELD, that the plant has some adjustment mechanism - plasticity -, in other words, if the NDPM is low, the yield is compensated by increasing the rate of dry matter accumulation in grains. It has already been proved in common bean when evaluating the three primary components of grain yield, number of pods per plant $(\mathrm{X})$, number of grains per pod $(\mathrm{Y})$, as well as grain weight $(\mathrm{Z})$. Grain yield (W) is the product of X.Y.Z. If one of the axis is influenced by any environmental factor, another one may compensate by supporting yield (Lima and Ramalho, 2016). Thus, it is practically unfeasible to try to increase RATE and NDPM simultaneously, unless there is a favorable environmental condition with no stress throughout the cycle.

Table 7. Correlation estimates of traits two by two, number of days to flowering (NDF - days) and to physiological maturity (NDPM - days), rate of dry matter accumulation (RATE - g grain ${ }^{-1}$ day $\left.^{-1}\right)\left(\mathrm{x}^{3} 0^{3}\right.$ ) and grain yield (YIELD - kg/plot) in the mean of common bean hybrids and parents.

\begin{tabular}{llll}
\hline & NDF & NDPM & RATE \\
\hline YIELD & $0.40^{* *}$ & $0.35^{* *}$ & $0.18^{\mathrm{ns}}$ \\
NDF & & $0.72^{* *}$ & $-0.52^{* *}$ \\
NDPM & & $-0.43^{*}$ \\
\hline *. T test significant at $1 \%$ probability & &
\end{tabular}

$*: T$ test significant at $1 \%$ probability

\section{CONCLUSIONS}

For NDF, NDPM and RATE, the general combining ability (GCA) explained most of the variation, indicating the predominance of additive effects in the control of these characters. Both GCA-and the specific combining ability (SCA) were important for grain yield. However, in relation to this trait, the estimate of heterosis was only significant, but negative $(-27.7 \%)$, when the crosses involved the Andean x Mesoamerican lines. The 
estimated values of correlation between NDPM x NDF were positive, and negative between NDF $x$ RATE and NDPM x RATE . Consequently, none of the common bean populations presented potential for obtaining new lines with high grain yield, with indirect selection for early flowering, and traits associated with grain filling.

\section{ACKNOWLEDGMENTS}

The authors thank the FAPEMIG (Fundação de Amparo à Pesquisa do Estado de Minas Gerais), for granting scholarship and financial support to "Sandwich Doctorate"scholarship and the Brazilian National Council for Scientific and Technological Development (CNPq) for granting the scholarship.

\section{CONFLICTS OF INTEREST}

The authors declare no conflict of interest.

\section{REFERENCES}

Andrade CA, Scapim CA, de Lucca , and Martorelli DT (2009) Produtividade, crescimento e partição de matéria seca em duas cultivares de feijão. Acta Scient. Agron. 31(4): 683-688. Doi: 10.4025/actasciagron.v31i4.6397

Araujo EF, Araujo RF, Sofiatti V and Silva RF (2006). Qualidade fisiológica de sementes de milho-doce colhidas em diferentes épocas. Bragantia. 65(4): 687-692. Doi:10.1590/S0006-87052006000400020.

Aude MIS, Marchezan E, Mairesse LAS, Bisognin, DA, et al. (1994). Taxa de acúmulo de matéria seca e duração do período de enchimento de grão do trigo. Pesq Agropec Bras. 29(10): 1533-1539.

Baldoni AB, Ramalho MAP and Abreu AFB (2008). Allele frequency and selection efficiency in cross populations of Andean x Mesoamerican common bean. Genet. Mol. Biol. 31(4): 914-919. Doi:10.1590/S141547572008005000008 .

Borel JC, Ramalho MAP, Carvalho VRF and Abreu ÂDFB (2013). Genetic and phenotypic parameters in common bean segregant populations from intra and inter-gene pool crosses of elite lines. Euphytica. 193(1): 39-47. Doi: 10.1007/s10681-013-0907-1.

Borel JC, Ramalho MAP and Abreu AFB (2016). Epistasis in intra-and inter-gene pool crosses of the common bean. Genet. Mol. Res. 15(1): 15017573. Doi:10.4238/gmr.15017573

Bruzi AT, Ramalho MAP and Abreu ÂFB (2007). Desempenho de famílias do cruzamento entre linhagens de feijões andinos e mesoamericanos em produtividade e resistência a Phaeoisariopsis griseola. Ciênc. agrotec. 31(3): 650655. Doi: 10.1590/s1413-70542007000300008.

Borráz L, Westgate ME, and Otegui ME (2003). Control of kernel weight and kernel water relations by post-flowering source-sink ratio in maize. Ann. Bot. 91(7): 857-867. Doi. 10.1093/aob/mcg090.

Borráz L, Zinselmeier C, Senior ML, Westgate ME, et al. (2009). Characterization of grain-filling patterns in diverse maize germplasm. Crop Sci. 49(3): 999-1009. Doi: 10.2135/cropsci2008.08.0475.

Chung JH and Stevenson E (1973). Diallel analysis of the genetic variation in some quantitative traits in dry beans. New Zealand J. Agric. Res. 16(2): 223-231. Doi:10.1080/00288233.1973.10421139.

Cruz JL, Ramalho MAP, Martins LA and Pelacani CR (1993). Relação entre rendimento, componentes primários de rendimentos e parâmetros de enchimento dos grãos de feijoeiro. Rev. Bras. Fisiol. Veg. 5(2): 159-162.

Cruz CD (2013). Genes - a software package for analysis in experimental statistics and quantitative genetics. Acta Sci. Agron.y. 35(3): 271-276. doi: 10.4025/actasciagron.v35i3.21251.

Cruz CD, Regazzi AJ and Carneiro PCS (2012). Modelos biométricos aplicados ao melhoramento genético. (p. 512), Viçosa: UFV.

Ferreira RADC, Ramalho MAP, Toledo FHRB and Abreu ADFB (2015). Implications of the number of years assessment on recommendation of common bean cultivars. Plant Breed. 134(5): 599-604. Doi: 10.1111/pbr.12302.

Foolad MR and Bassiri A (1983). Estimates of combining ability, reciprocal effects and heterosis for yield and yield components in a common bean diallel cross. J. Agric. Sci. 100(1): 103-108. Doi: 10.1017/S0021859600032482.

Gasura E, Setimela P, Edema R, Gibson PT, et al. (2013). Exploiting grain-filling rate and effective grain-filling duration to improve grain yield of early-maturing maize. Crop Sci. 53(6): 2295-2303. Doi:10.2135/cropsci2013.01.0032.

Griffing BRUCE (1956). Concept of general and specific combining ability in relation to diallel crossing systems. Austral. J. Biol. Sci. 9(4): 463-493. Doi: 10.1071/BI9560463. 
Guilherme SR, Ramalho MAP, Abreu AFB and Pereira LA (2014). Genetic control of inflorescence in common bean. Genet. Mol. Res. 13(4): 10349-10358. Doi: 10.4238/2014.

Lee EA and Tollenaar M (2007). Physiological basis of successful breeding strategies for maize grain yield. Crop Sci. 47(Supplement_3): 202-215. Doi: 10.2135/cropsci2007.04.0010IPBS

Lima LKD, Ramalho MAP and Abreu ÂDFB (2013). Selection of common bean inbred lines with tolerance to high moisture at harvest. Ciên Agrotec. 37(2): 152-158. Doi: 10.1590/S1413-70542013000200006.

Lima J and Ramalho MAP (2016). Geometry applied to breeding common beans (Phaseolus vulgaris). Genet. Mol. Res. 15: 1-8. Doi: 10.4238/gmr.15027873.

Martins ES, Pinto Junior RA, Abreu AFB and Ramalho MAP (2017). Genetic control of number of flowers and pod set in common bean. Genet. Mol. Res. 16(3). Doi:10.4238/gmr16039723.

Mendes MP, Botelho FBS, Ramalho MAP, Abreu ÂDFB, et al. (2008). Genetic control of the number of days to flowering in common bean. Crop Breed Appl Biotechnol. 8: 279-282. Doi:10.12702/1984-7033.v08n04a04.

Moreto AL, Ramalho MAP, Nunes JAR and Abreu ÂDFB (2007). Estimação dos componentes da variância fenotípica em feijoeiro utilizando o método genealógico. Ciência e agrotecnologia. 31(4): 1035-1042. Doi:10.1590/S141370542007000400014.

Moreto AL, Ramalho MAP and Bruzi AT (2012). Epistasis in an Andean $\times$ Mesoamerican cross of common bean. Euphytica. 186(3): 755-760. Doi: 10.1007/s10681-011-0578-8.

Müller BSF, Sakamoto T, Silveira RDD, Zambussi-Carvalho PF, et al. (2014). Differentially Expressed Genes during Flowering and Grain Filling in Common Bean (Phaseolus vulgaris) Grown under Drought Stress Conditions. Plant Mol. Biol. Rep. 32: 438-451. Doi: 10.1007/s11105-013-0651-7.

Oliveira LD, Ramalho MAP, Abreu ÂDFB and Ferreira DF (1996). Alternative procedures for parent choice in a breeding program for the common bean (Phaseolus vulgaris L.). Braz. J. Genet. 19(4): 611-615. Doi: $10.1590 / \mathrm{S} 0100-84551996000400014$.

Pereira HS, dos Santos JB, Abreu ÂDFB and Couto KR (2007). Informações fenotípicas e marcadores microssatélites de QTL na escolha de populações segregantes de feijoeiro. Pesq. Agropec. Bras. 42(5): 707-713. Doi:10.1590/s0100 $204 \times 2007000500014$.

R Core Team (2017). R: A language and environment for statistical computing. R Foundation for Statistical Computing, Vienna, Austria. URL https://www.R-project.org/.

Ramalho MAP, Abreu AFB and Guilherme SR (2014). Anais da 20a Reunião da Comissão Técnica Central Brasileira de Feijão. Informações técnicas para o cultivo do feijoeiro-comum na Região Central-Brasileira: 2015-2017. (p. 168), Lavras: Ed. UFLA.

Ramalho MAP, Abreu AFB, Santos JD and Nunes JAR (2012). Aplicações da genética quantitativa no melhoramento de plantas autógamas. (p. 522), Lavras, UFLA.

Ramalho MAP and Ferreira MM (1979). Comportamento de cultivares de feijão (Phaseolus vulgaris L.) em relação ao florescimento e vingamento das vagens. Cienc. Pratica. 3: 80-83.

Reis WP, Ramalho MAP and Cruz JC (1985). Arranjos e populações do feijoeiro na consorciação com o milho. Pesq Agropec. Bras. 20: 575-584.

Santos JB, Gavilanes ML, Vieira RF and Pinheiro LR (2015). Botânica. In: Carneiro, J. E. S., Paula Júnior, T. D., and Borém, A. Feijão: do plantio à colheita. (p. 314), Viçosa: Ed. UFV.

Shii CT, Mok MC and Mok DW (1981). Developmental controls of morphological mutants of Phaseolus vulgaris L.: differential expression of mutant loci in plant organs. Genesis. 2(3): 279-290. Doi: 10.1002/dvg.1020020306.

Silva NO, Ramalho MAP, Abreu, ÂFB and Carneiro JEDS (2004). Performance of common bean families after different generations under natural selection. Genet Mol. Biol. 27(4): 574-578. Doi: 10.1590/S1415-47572004000400018.

Taiz L and Zeiger E (2013). Crescimento e desenvolvimento. In: Taiz, L., and Zeiger, E. (Ed.). Fisiologia vegetal. (p. 365-400), 5 ed. Porto Alegre: Artmed.

Vilarinho LBO, Vilarinho AA, Moreira MA and Barros EG (2004). Evaluation of the Milionário bean cultivar as bridgecrossing between 'Rudá' and 'Jalo EEP 558'. Crop Breed Appl Biotechnol. 4(4): 241-243. Doi: 10.12702/19847033.v04n03c04.

Vieira EHN and Vieira NRA (1997). Indicadores visuais da maturação fisiológica do feijão. (p. 22) EMBRAPA, Goiânia: Embrapa-CNPAF-APA, (Documento 73).

Zilio M, Coelho CMM, Souza CA, Santos JCP, et al. (2011). Contribuição dos componentes de rendimento na produtividade de genótipos crioulos de feijão (Phaseolus vulgaris L.). Rev Ciênc Agron. 42(2). Doi: $10.1590 / \mathrm{s} 1806-66902011000200024$. 